\title{
Identifying the information needs of public library and information services users in Limpopo province
}

\author{
Solomon Bopape ${ }^{1}$, Maoka Dikotla², Matlala Mahlatji ${ }^{3}$, \\ Morongoenyane Ntsala ${ }^{4}$ and Lefose Makgahlela ${ }^{5}$ \\ Solomon.Bopape@ul.ac.za ORCID: orcid.org/0000-0003-3389-2378 \\ Maoka.Dikotla@ul.ac.za ORCID: orcid.org/0000-0002-6699-6782 \\ Rachel.Mahlatji@ul.ac.za ORCID: orcid.org/ 0000-0002-3504-4260 \\ Morongoe.Ntsala@ul.ac.za ORCID: orcid.org/0000-0001-9362-/5445 \\ Lefose.Makgahlela@ul.ac.za ORCID: orcid.org/ 0000-0003-1433-2527
}

\begin{abstract}
Received: 30 January 2017
Accepted: 27 April 2017

Public libraries are indispensable institutions that contribute towards the socio-economic development of every citizen in every country by providing access to information. In South Africa, the provision of access to information through public libraries was marred by the inequalities of the apartheid laws. In order to address past injustices regarding access to information, the government of today, through the Department of Arts and Culture, is committed to allocating an annual library conditional grant to all the nine provinces to build and develop new and already existing public libraries, respectively. This study investigated the information needs of people who use these newly built and developed public libraries and information centres in Limpopo Province. The questionnaire was distributed to the library users of selected public libraries in Limpopo Province to collect information about their basic information needs and expectations. The results showed that the majority of public libraries and information services users in Limpopo Province are the youth and young adults, who specifically use these libraries and information services for study space and accessing the internet. The kind of information required by these youth, young adults and adults revolves around health matters, education programmes, career guidance and crime prevention. It is therefore recommended that library users be made aware of other services offered by public libraries and that user needs analysis studies be conducted from time to time in order for public libraries to meet the ever-changing needs of library users.
\end{abstract}

Keywords: Information needs, library users, rural communities, public libraries, information services, Limpopo province

\section{Introduction}

Several organisations and individuals share the sentiment regarding the importance of public libraries and their role in the improvement of quality of life for citizens in every country. Along these lines, Davis (2009: 131) contended that "the public library should contribute towards the improvement of the quality of life, play a role in education, the promotion of moral values, the eradication of illiteracy, the alleviation of poverty and the promotion of democracy in society". In its public library manifesto (IFLA/UNESCO 1994), the International Federation of Library Associations and Institutions stated its belief in the public library as "a living force for education, culture and information". Fourie and Meyer (2016) have said that "libraries and librarians can play a prominent and successful role in developing informed and educated, as well as empowered, nations". In The Library and Information Services (LIS) Transformation Charter (Nkondo et al. 2014: 53), a public library is recognised as "an essential component of a modern democracy, an enduring agency tasked with providing opportunities for education, culture, literacy, and information provision to reach all citizens free of charge". Ocholla (2006) noted that "essentially, the role of libraries are to inform, entertain, enlighten, educate, empower and equip individuals and communities for lifelong learning in order that they can know their rights and responsibilities in the society to fulfil their social roles knowingly and responsibly".

Despite the recognition by several organisations and individuals of the importance of public libraries in the socioeconomic development of citizens, the provision of access to information through public libraries and information centres has been marred by a number of challenges that are manifested more acutely in rural areas of South Africa. Davis (2009:131) noted that "ever since 1994 there seems to be worrisome aspects and uncertainty regarding the place of public libraries within South African local and provincial governments". Rodrigues, Jacobs and Cloete (2006: 212) outlined the past, unequal and segregated cultural context within which public libraries developed in South Africa.

1. Solomon Bopape is Acting Head of Department of Media, Communication and Information Studies, University of Limpopo

2. Maoka Dikotla is Senior Lecturer and Programme Coordinator, Programme of Information Studies, University of Limpopo

3. Matlala Mahlatji is Lecturer, Programme of Information Studies, University of Limpopo

4. Morongoenyane Ntsala is Lecturer, Programme of Information Studies, University of Limpopo

5. Lefose Makgahlela is Lecturer, Programme of Information Studies, University of Limpopo 
In Limpopo Province, the situation is aggravated by the fact that public libraries in the province operate in urban areas whereas a greater percentage of the population is based in rural areas without wider access to basic library and information services, and where poverty, illiteracy and unemployment are prevalent (Mokgaboki 2002:78). However, recently, the democratic government in South Africa, through the Department of Arts and Culture (DAC), has made available the conditional Community Library Services Grant to redress the imbalances and inequalities in the LIS sector by improving and refurbishing existing library and information services, establishing new libraries and purchasing new books for public libraries. This conditional grant is allocated annually by the Department of Arts and Culture to all the nine provinces in South Africa (Malotle and Selwana 2016: 11).

According to The South African Libraries 20 years review (Department of Arts and Culture and National Library of South Africa 2014) the DAC, in collaboration with provincial departments of sports, arts and culture, are coordinating the implementation of the community library conditional grant. The purpose of the grant is to address specific inequalities in the delivery of public library services to all communities. DAC and the provincial departments of arts and culture work together to reach certain predetermined targets, which are:

- $\quad$ improved coordination and collaboration between national, provincial and local government on library services;

- $\quad$ transformed and equitable library and information services delivered to all rural and urban communities;

- $\quad$ improved library infrastructure and services that reflect the specific needs of the communities they serve;

- $\quad$ improved staff capacity at urban and rural libraries to respond appropriately to community knowledge and information needs; and

- improved culture of reading.

The Community Library Services Grant was deployed in 2007 with the allocation of R1 billion for a period of three years. It is estimated that R1.8 billion would be spent for this purpose in the cycle 2012/13 to 2014/15 (Department of Arts and Culture and National Library of South Africa 2014). As such, it is assumed that the new three-year cycle starts in 2016 /2017. Additionally, the Mzansi Libraries Online project provides "pilot libraries an opportunity to redefine the public library services based on free internet access to information; introduction and incorporation of new technologies in existing and new services; re-designed spaces and technology infrastructure; and training and development of library end-users and staff, based on identified training needs" (Matolong 2014). Efforts of this nature from the government are set to guarantee more access to an uninterrupted use of internet services in community and public libraries across the country.

As one of the recipients of a DAC conditional grant, the provincial Department of Sport, Arts and Culture in Limpopo was able to build a number of new public libraries in the rural areas, refurbish already-existing public libraries and purchase new books for public libraries ${ }^{6}$. It is essential to assess whether libraries built or improved thanks to the grants are relevant to the information needs of the communities they serve. This can only be achieved if the information needs of library users are first identified, assessed and analysed.

It has been constantly lamented that the public library and information services sector in South Africa is rooted in its colonial past. Most of South Africans' understanding of the service is derived from the public library backgrounds of other countries that are based on Anglo-American and Eurocentric library practices (Stilwell 1989; Witbooi 2007). According to Davis (2009:132), "public libraries in Africa have for a long time operated without fully taking into consideration the needs and interests of the people expected to use them". Each of the nine provinces in South Africa should therefore develop a LIS model of its own that will be suitable to the information needs and expectations of its communities. Maepa (2000) emphasised that "in order for public or community LIS to respond to the daily needs and expectations of villagers, they need to know what their information needs and interests are".

The introduction of internet access in public libraries also calls for the systematic analysis and understanding of the information needs of the communities served by the new and improved libraries and information centres in Limpopo Province. Perhaps, research on identifying the current basic information needs of the communities could be of assistance to future planning of these sort of centres in Limpopo Province. The aim of this study was to investigate users' needs and expectations of community libraries in Limpopo Province.

The study sought to:

- $\quad$ establish the primary users of public libraries and information services in Limpopo Province;

- $\quad$ identify the major reason for visiting the public library and information services, and resources sought by public library users in Limpopo Province; and

- measure how important the different kinds of information sources and services are to users of library services in Limpopo Province.

6. The Limpopo Department of Sport, Arts and Culture, through its Library and Information services unit, plays a vital role in promoting public libraries and archives in the province through the improvement of access to library facilities and the promotion of a sustainable reading culture. Currently, the department is managing a total of sixty-eight libraries through approved service level agreements with the municipalities. Included in this number are ten recently-built libraries spread through all the Provincial Districts. This development will provide the necessary after-hours reading facility that previous designs failed to accommodate. However, the reduction in the current year's conditional grant allocation to the province had a negative impact on planned projects. The department was compelled to reduce to two from the initial four new library projects that were planned (Limpopo Department of Sport, Arts and Culture 2015). 
Bothma and Bergenholtz (2013) remarked that information needs change from time to time and that, in as much as there are stable information needs on which public libraries base services and programmes, there are also unstable information needs that must be determined by libraries, librarians and LIS researchers. Instability implies change, therefore, information needs may change from time to time. Therefore, this study looks into what are the information needs of the communities in these changing times. By studying the information needs of the community to be served, the public libraries and information services in Limpopo Province will be able to provide the right information to the right people at the right time. Worcester and Westbrook (2004: 102) explained that "community needs analysis offer librarians a means to develop and review their own current services and programmes, and then use the results to plan for new library services and programmes". Mnkeni-Saurombe (2010: 92) has also noted that "needs are prioritised, [and] products and services are tailor made to address the needs".

\section{Literature Review}

The concept 'information needs' has proven to be an elusive one, difficult to define, isolate and measure, because information needs are affected by many factors (Kumar 2008). Nicholas (2000:19) commented that "when definitions of the concept information needs are provided, they are often vague or highly complex, and further that people often talk about information needs when, in fact they are referring to information wants and demands". Evans and Saponaro (2012: 41) and Chowdhury and Chowdhury (2011: 27) provided the definitions of and differentiated between the three terms, 'needs', 'wants', and 'demands'; Case (2012: 80) differentiated between the terms 'needs' and 'demands'. In this study, emphasis is placed on the term 'need' in order to provide a working explanation of the concept 'information needs'.

A need is said to be "a subjective experience that occurs only in the mind of a person in need" (Wilson 1997: 552). For instance, when a person experiences a problem or wants to accomplish a particular task and does not know how to tackle that problem or how to accomplish that task, a need for information arises. When they obtain and use information, their needs can be fully or partly met. Case (2012: 78) suggested that 'needs' are "typically characterised as an 'inner motivational state' that brings about thought and action". Morgan and King (1971 in Wilson 1997:553) suggested that needs emerge from three kinds of motives, namely, physiological motives such as hunger and thirst, unlearned motives such as curiosity of sensory stimulation, and social motives such as desire for affiliation, approval or status. Based on the explanations above, an information need appears not to be a primary need, but a secondary need that arises out of another need of a more basic kind (Wilson 1999: 252; Chowdhury and Chowdhury 2011: 26). These explanations entail that information needs are generated by the situations in which people find themselves. These situations generate needs, and these needs become information needs when people in those situations do not know how to deal with a situation.

Wilson (1981) proposes "a model of the situations within which the need for information arises as well as the barriers that may exist when one engages in information-seeking behaviour". When a person finds himself or herself in a particular situation where a gap in knowledge of the situation triggers a conscious search for information, three sets of barriers to information seeking are shown. These barriers are related to the dimensions of the situation in which the person finds himself or herself, namely, personal, social or role-related, and environmental. In Wilson's revised information-seeking behaviour model of 1996, these barriers are referred to as intervening variables and include personal characteristics (emotional, educational and demographic), social or interpersonal, and environmental (economic and source characteristics) variables (Wilson 1997). The impact of these intervening variables may be supportive as well as preventative of information use (Wilson 1999: 256). Psychological variables may refer to individuals' outlook on life and their system of values, political orientation, knowledge, and style of learning, as well as other traits of the individual information seeker (Heinström 2003). Interpersonal variables entail that the role a person plays places him or her in a particular place in the social system and in an organisation, which creates certain opportunities or barriers to information use. Environmental variables can include legislation, economic level, level of stabilisation, information culture and such, where the wider environment in which people find themselves may create problems and opportunities for them to gain access to information (Niedzwiedzka 2003).

The analysis of users' information needs should therefore include an overview of the users themselves (their personal and psychological traits) in order to understand their experiences, problems, backgrounds, their tasks and roles, the environments in which they live, as well as their expectations so that librarians should be able to determine what information they are likely to require from the library. Demographic characteristics such as age and gender distribution; educational levels; sources and levels of incomes; occupation; and other characteristics of the population being served by the library must also be assessed and analysed in order to identify what its information needs are. Evans and Saponaro (2012: 55) acknowledged that demographic data are essential for formulating an effective library collection development programme and further that such information helps to identify the population distribution changes and trends that will affect library service needs.

It should also be acknowledged that several classes of users consume different kinds of information for different purposes. Wilson (1997: 564) made mention of preferred information sources and channels. Aina (2004) emphasised that every individual, whether literate or not, has information needs - the information need could be for recreation and leisure, to complete tasks that are considered critical for survival, or for information that could meet day-to-day activities. Wilson (1994) noted that information needs vary in relation to the subject fields of users, their educational background, and years of experience or function performed. Accordingly, users of public libraries make use of libraries for various reasons. In the current study, library users were asked to provide their reasons for visiting public libraries.

In Kebede (2002:14), it was noted that information needs are also stimulated by the information resources and services that are available in the library. The knowledge of what facilities and materials are available to them is among the factors 
that influence information needs of users. Wilson (1997: 561) identified information-source characteristics such as accessibility and credibility as some of the factors that influence information needs in the information-seeking process. Therefore, in order to identify the information needs of library users, they should also be asked about the information services and resources that they use in their public libraries.

\section{Methodology}

The study adopted a quantitative research approach through the use of a questionnaire comprising mainly closed questions. Limpopo Province is divided into five districts, namely, Mopani, Vhembe, Capricorn, Waterberg, and Greater Sekhukhune. According to the National Library of South Africa (2012:68), there are ninety-four public and community libraries in all five districts of Limpopo Province. Based on the fact that no study can address everything, the present study selected the libraries using convenience sampling whereby the researchers visited only the libraries that were easily accessible and known to them. In total, seventeen libraries from all the districts in Limpopo Province participated in the study. Capricorn district had the highest number of libraries that participated in the study (seven) followed by Vhembe, Mopani and Greater Sekhukhune districts with three libraries each, and lastly, Waterberg district with only one library. In each of the libraries, fifteen to twenty questionnaires with the same questions were given to the librarians to distribute to library users who were in those libraries at that time. In libraries where there were no users during that time, the questionnaires were left with the librarians to give to the users to complete when they visited the library, and then collected after a period of two weeks by the researchers. A total of 211 out of the 250 questionnaires that were distributed were completed and returned to the researchers (84\%). Based on the fact that each district was represented in this study, the response rate of this nature was sufficient to enable generalising the results to the target population.

\section{Results and Discussion}

The results cover demographic data of respondents, library membership, main reasons for visiting the libraries, as well as the degree of importance attached to different kinds of information resources and services.

\subsection{Demographic data}

In this section, the study sought to assess the demographic data of the communities served by the public libraries and information services in Limpopo Province. Evans (1992: 16) emphasised that, for a library to develop its collections and services, its librarians need to know who their constituencies are, as well as their interests; their levels of interests in reading and information resources; and their literacy or educational levels.

Furthermore, librarians should also assess the circumstances in which members of the communities live, as these trigger them to seek information in one way or another. Knowledge of the information needs of the communities served by public libraries can only be obtained through analysing their demographic data. This study accordingly started by analysing the demographic profile of the users, such as gender, age, educational level, sources of income, and such.

The results depicted in Table 1 show that, out of 211 questionnaires, $120(57 \%)$ respondents were males, while ninetyone $(43 \%)$ were females. With regards to age, the highest age group of all respondents was the 19-30 years age group, represented by $113(53 \%)$ respondents; followed by thirty-eight (18\%) respondents whose age group fell between 31 and 40 years; those whose age group fell between 15 to 18 years were represented by thirty-two (15\%) respondents. Sixteen $(8 \%)$ respondents were those whose age group was between 41 and 50 years. The smallest age group of all the respondents was that of those who are above 61 years old, represented by four respondents ( $2 \%$ ); followed by those whose age ranged between 51 and 60 years, represented by eight respondents (4\%). These numbers reveal that most of the respondents in this study were the youth and young adult males.

With regards to educational level, the majority of the respondents had matric and a diploma (either from a University of Technology or Technical and Vocational Education and Training (TVET) College), represented by sixty (29\%) respondents; followed by those with a bachelor's degree and secondary education, represented by thirty-five (17\%) and thirty $(15 \%)$ respondents respectively. None of the respondents had a master's or a doctoral degree. The lowest number, at three (4\%), had an honours degree, followed by nine respondents (4\%) who had a postgraduate diploma. Seven did not respond to the question regarding their educational level.

Table 1 further shows that the majority of respondents, at ninety-five (45\%), had no stable income, while fifty-one (24\%) depended on a salary for a living. Twenty-seven (13\%) were self-employed and twenty-five (12\%) depended on social grants. The respondents whose source of income is a pension fund were six (3\%), while seven (3\%) depended on other sources of income.

When asked about their occupations, it was found that, out of 199 respondents who answered the question, the majority of the respondents, at $101(51 \%)$, were students or learners, while thirty (15\%) had no occupation at all. The remaining respondents were nine teachers (5\%), five pensioners (3\%), four nurses (2\%), three policemen/women (1\%), one domestic worker and one farm worker. Forty-five (23\%) respondents' occupations were other than the ones listed, which were not specified.

This study seems to have occurred among the youth and young adults ${ }^{7}$. Perhaps one of the main causes for more youth and young adult respondents is the time during which data were collected for this study, that is, during the examination

7. The National Youth Policy 2014-2019 defines youth as any persons between the ages of 14 and 35 years, whereas the White paper for social welfare (Department of Welfare 1997) defines a young person as a woman or man aged between 16 to 30 years. 
period. Public libraries are regarded as neutral and safe public spaces that provide opportunities for the youth to grow intellectually and socially; to develop new literacies for learning and expression; and to gain workplace preparedness (Braun et al. 2014). A study by Hart (2004) found that a high number of learners use township public libraries, especially in the afternoons. This is likely because of the general shortage of school libraries in South Africa. In addition, for the schools that have libraries on their premises, such are closed after school hours.

Table 1 Demographic data of library users

\begin{tabular}{|c|c|c|c|}
\hline Variable & Distribution & Number & Percentage \\
\hline \multirow{4}{*}{ Gender (N=211) } & Male & 120 & $57 \%$ \\
\hline & Female & 91 & $43 \%$ \\
\hline & $15-18$ & 32 & $15 \%$ \\
\hline & $19-30$ & 113 & $53 \%$ \\
\hline \multirow{8}{*}{ Age $(\mathrm{N}=211)$} & $31-40$ & 38 & $18 \%$ \\
\hline & $41-50$ & 16 & $8 \%$ \\
\hline & $51-60$ & 8 & $4 \%$ \\
\hline & $61 \mathrm{yrs}$. Above & 4 & $2 \%$ \\
\hline & No education & 3 & $2 \%$ \\
\hline & Primary education & 4 & $2 \%$ \\
\hline & Secondary Education & 30 & $15 \%$ \\
\hline & Matriculation & 60 & $29 \%$ \\
\hline \multirow{8}{*}{ Education ( $N=204)$} & Diploma & 60 & $29 \%$ \\
\hline & Bachelor's degree & 35 & $17 \%$ \\
\hline & Postgraduate Dip & 9 & $4 \%$ \\
\hline & Honours & 3 & $2 \%$ \\
\hline & Masters & 0 & 0 \\
\hline & Doctoral Degree & 0 & 0 \\
\hline & No income & 95 & $45 \%$ \\
\hline & Social Grant & 25 & $12 \%$ \\
\hline \multirow{8}{*}{ Source of income $(\mathrm{N}=211)$} & Pension grant & 6 & $3 \%$ \\
\hline & Salary & 51 & $24 \%$ \\
\hline & Self-employed & 27 & $13 \%$ \\
\hline & Other & 7 & $3 \%$ \\
\hline & No occupation & 30 & $15 \%$ \\
\hline & Student /learner & 101 & $51 \%$ \\
\hline & Teacher & 9 & $5 \%$ \\
\hline & Nurse & 4 & $2 \%$ \\
\hline \multirow[t]{5}{*}{ Occupation ( $N=199)$} & Domestic Worker & 1 & $0 \%$ \\
\hline & Farm Worker & 1 & $0 \%$ \\
\hline & Police man / woman & 3 & $1 \%$ \\
\hline & Retired / pensioner & 5 & $3 \%$ \\
\hline & Other & 45 & $23 \%$ \\
\hline
\end{tabular}

\subsection{Library membership}

Figure 1 shows that seventy-one (34\%) respondents were registered as members of the library as opposed to $124(60 \%)$ who were not. Thirteen $(6 \%)$ did not answer this question. The results reveal that most of the participants were not registered as members of libraries, probably because membership requires parents' signatures (Hart 2004: 115). 
Figure 1 Library membership

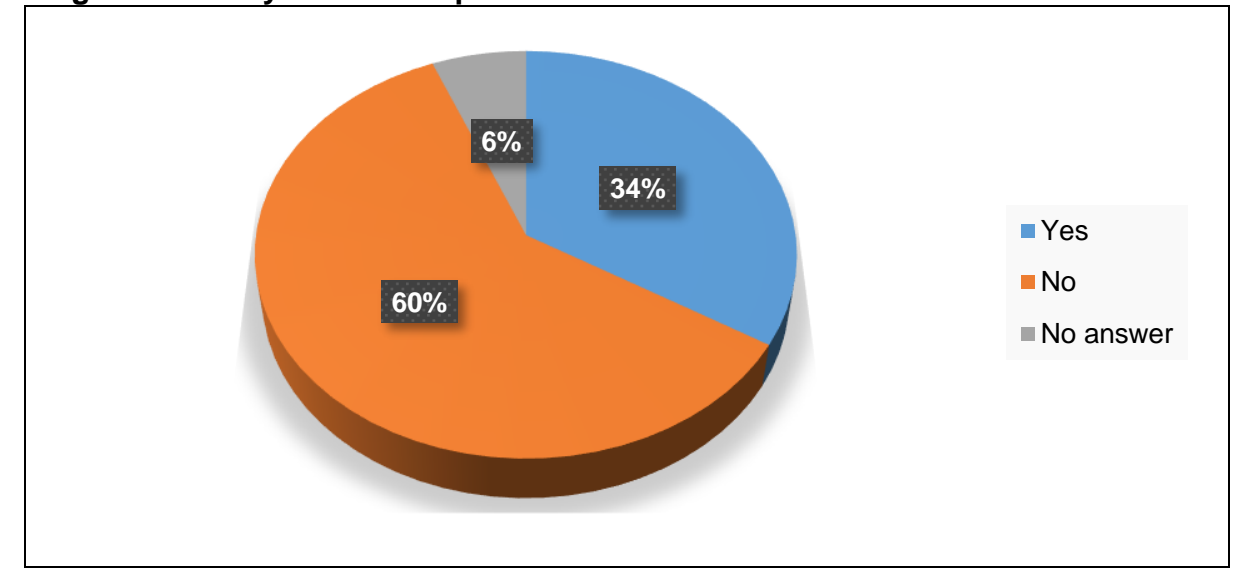

\subsection{Reasons for visiting the library}

In this section, the respondents were requested to choose from a number of options about the main reasons for visiting the library on the day on which they received the questionnaire. The results (Figure 2) indicated that the main reasons for visiting public libraries were as follows: to find a study place (fifty-three respondents) and searching the internet (fifty respondents). Other reasons were: for reference and research purposes, reading newspapers, and reading non-fiction books.

Figure 2 Main reasons for visiting the library

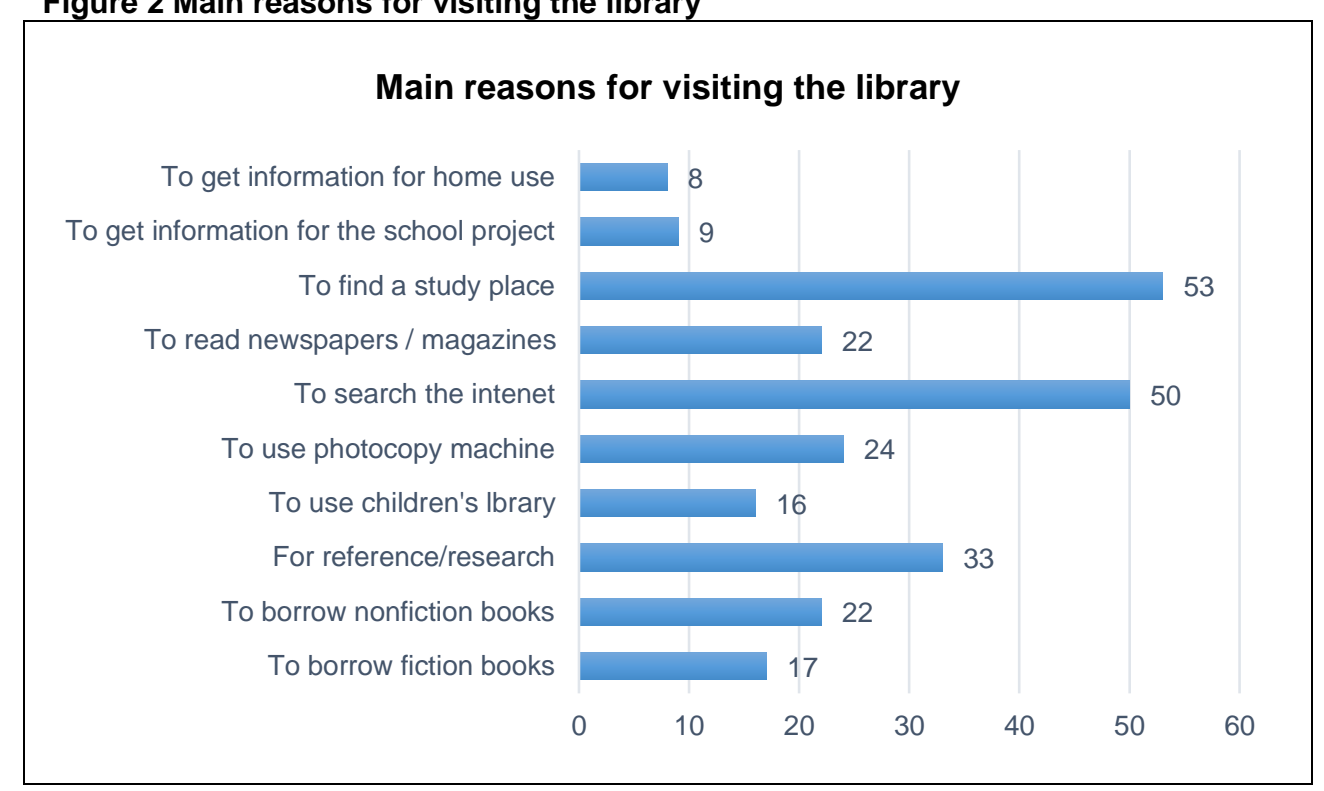

Finding a conducive place to study is the main reason why most people visited the public libraries. Most of the users dwell in rural-based households, where they do not have conditions at home that are conducive to study (Hart 2004:15). Therefore, a library is a quiet space where these students can study. Wishart (2012) commented that Africans who live in one-room mud brick homes have a great need for a quiet place to read. This could be the same for people living in what is commonly referred to as 'RDP houses' in which many low-income earners dwell in in South Africa today ${ }^{8}$. Sturges and Neil (2004:180 in Wilshart 2012) stated that "for many people it is the struggle for quiet that is most important". Raseroka (1986: 288 in Wilshart 2012) noted that "students' need for public libraries stem from ... the need for an environment which is supportive of studying ... a quiet area of study, a well-lit place of study...". Most people in the developed world have comfortable homes that provide quiet spaces; in underdeveloped countries, homes have no place for quiet study, and a library can fill that need.

When studying, students are obliged to make references to materials used when writing assignments and school projects. According to Fourie ( 2007) and Hart and Nassimbeni (2013), it has been discovered in several studies that youth

8. After 1994, the ANC government in South Africa implemented the Reconstruction and Development Policy (RDP) framework, with the aim of addressing the socio-economic challenges that the people of South Africa suffered as consequences of the laws of the previous apartheid regime. Among some of these challenges was the severe housing backlog in the country. In order to provide housing to the previously disadvantaged communities of South Africa, the ANC government initiated building free and low-cost housing units, which are commonly referred to as RDP houses. 
and young adults are drawn to libraries to access the library's internet or computers, use the library's research resources, and study, read and write assignments for their school projects. Kebede (2002:15) argued that the current changes from print to electronic forms in which information is made available has brought about changes in the information needs of users. The majority of library users today visit the libraries to search for information from the internet. There are several purposes for which the internet can be used in public libraries, including social networking, open distance learning, employment searching, and e-government self-help services.

\subsection{Importance of different kinds of information}

As shown in Table 2, the respondents were asked to indicate the degree of importance they attach to different kinds of information. A four-point Likert scale was used where participants were asked to show how important different kinds of information provided by the libraries was to them. The results show that all kinds of information are important, but most respondents viewed information on health matters, educational programmes, and career guidance as very important, with $147(70 \%), 139(66 \%)$, and $122(58 \%)$ respondents respectively rating these highly. Poor health services in sub-Saharan Africa is one of the enormous challenges that the region faces. Hart (2010: 83) mentioned child mortality, maternal health complications among women, HIV/AIDS and malaria as some of the health issues that both sub-Saharan Africa and South Africa need to eradicate as part of their Millennium Development Goals.

Table 2 Degree of importance attached to different kinds of information $(\mathrm{N}=211)$

\begin{tabular}{lcccc}
\hline Kind of information & $\begin{array}{c}\text { Not important } \\
\text { at all }\end{array}$ & Not Important & Important & $\begin{array}{c}\text { Very } \\
\text { important }\end{array}$ \\
\hline Business matters & $16(8 \%)$ & $38(18 \%)$ & $60(28 \%)$ & $95(45 \%)$ \\
Career guidance & $15(7 \%)$ & $10(5 \%)$ & $64(30 \%)$ & $122(58 \%)$ \\
Crime prevention & $10(5 \%)$ & $14(7 \%)$ & $68(32 \%)$ & $119(57 \%)$ \\
Educational programmes & $19(9 \%)$ & $25(12 \%)$ & $28(13 \%)$ & $139(66 \%)$ \\
Entertainment & $24(11 \%)$ & $24(11 \%)$ & $68(32 \%)$ & $91(43 \%)$ \\
Family planning & $38(18 \%)$ & $14(6 \%)$ & $58(27 \%)$ & $100(47 \%)$ \\
Food and nutrition & $22(10 \%)$ & $36(17 \%)$ & $63(30 \%)$ & $90(43 \%)$ \\
Health matters & $6(3 \%)$ & $10(5 \%)$ & $48(23 \%)$ & $147(70 \%)$ \\
Legal matters & $44(21 \%)$ & $37(17 \%)$ & $59(28 \%)$ & $71(34 \%)$ \\
Local community events & $48(23 \%)$ & $73(35 \%)$ & $42(20 \%)$ & $48(23 \%)$ \\
Local History & $34(16 \%)$ & $47(22 \%)$ & $52(25 \%)$ & $78(37 \%)$ \\
Local news & $27(13 \%)$ & $44(21 \%)$ & $59(28 \%)$ & $81(38 \%)$ \\
Local social services & $34(16 \%)$ & $44(21 \%)$ & $52(25 \%)$ & $78(37 \%)$ \\
Money loans & $75(35 \%)$ & $90(43 \%)$ & $12(5 \%)$ & $13(6 \%)$ \\
Politics & $28(13 \%)$ & $97(46 \%)$ & $20(9 \%)$ & $62(29 \%)$ \\
Religion & $18(9 \%)$ & $30(14 \%)$ & $80(38 \%)$ & $66(31 \%)$ \\
Sports & $26(12 \%)$ & $44(21 \%)$ & $56(27 \%)$ & $78(37 \%)$ \\
Weather & $19(9 \%)$ & $10(5 \%)$ & $61(30 \%)$ & $121(57 \%)$ \\
\hline
\end{tabular}

On HIV/AIDS, Schoombee, Cloete and Jacobs (2008: 17) lamented that "the pandemic already affects South Africa in various sectors, such as economic development, education, welfare spending health and labour". Therefore, health information is regarded as being the most important by the respondents who participated in this study. The provision of educational programmes is also regarded as the basic service that each public library should provide. Arko-cobbah (2005:349) emphasised that the traditional role of public libraries has been to support self-education of citizenry in order that they may participate fully in a democratic society. Hart (2004: 110) argued that educational transformation in South Africa, since 1994 offers the library profession an opportunity to take a more prominent role in education and social development. It is for this reason that most users of public library services view educational programmes information as being the most important.

With regards to career guidance, Fourie (2007: 51) acknowledged that young people in South Africa face a number of serious problems in terms of the educational system and employment. High rates of unemployment among the economically active youth, wrong subject choices at school, and poor examination results are the results of lack of career guidance. For this reason, they need and expect information on career guidance in the libraries as the educational support services of the Department of Education are hampered by financial constraints and low teacher ratios (Fourie 2007: 51). Crime also 
appears to be one of the problems in Limpopo Province ${ }^{9}$. Of the respondents, 199 (56\%) regard crime prevention information as "very important". This finding is contrary to the findings of the study by Mnkeni-Saurombe (2010) wherein information relating to crime prevention was ranked the lower.

\section{Conclusion}

In conclusion, there are two main areas of information, also identified by Stilwell (1989:261), that people need, namely, survival and citizen action information. Survival information includes information needed for health, housing, job security and security of resources, whilst citizen action information includes the need for information for effective participation in social, political and economic processes. Looking at the model on which this study is based, it is revealed that users of libraries and information services in Limpopo Province use libraries for the fulfilment of their roles as learners. Therefore personal, social, role-related and environmental conditions trigger a conscious search for information as depicted in Wilson's (1981) information-seeking behaviour model. Public libraries play an important role in providing such information for developing the lives of people, whether in economic, educational, cultural or social aspects of their lives. Therefore, access to information through the use of public or community libraries for the improvement of the economic conditions of citizens of every country cannot be over-emphasised.

In South Africa, access to information was skewed by the inequalities of the past. The new democratic government in South Africa deemed it fit to revitalise the provision of access to information through the establishment of the conditional Community Library Services Grant for the establishment and development of new and old library and information services in the country. The grant is augmented by the provision of internet access for library users in most public libraries. Limpopo Province is no exception to these new developments. Identifying the information needs of people served by these improvements is a point of departure for establishing how well these new and developed libraries meet the ever-changing information needs of the communities to be served. This study found that the users of these libraries are predominantly youth and young adults who make use of them for study space and internet access. The most basic information that users of these public libraries need include career guidance, educational programmes, health information and crime-prevention information. Therefore, education seems to be the predominant factor that triggers people to use public libraries.

Based on these findings, it is recommended that users realise that public libraries are not only meant to provide reading space and internet access to youth pursuing their studies. Public libraries may also be used to inform, educate and entertain users of all age groups through various sources and services. Public libraries should embark on awareness programmes educating community members about services that they offer and encouraging users of all age groups to use library services. User studies of this nature, where information needs of users are identified and analysed, should be conducted from time to time, so that library services and programmes can be tailor made to meet the ever-changing basic information needs of library users.

\section{Acknowledgement}

This paper reports part of the findings of a study sponsored by the South African Library and Information (SALI) Trust. Every year, the SALI Trust offers a number of grants in the field of Library and Information Services work in South Africa. One such grant is the research and development of librarianship and information work, which was awarded to the Programme of Information Studies, University of Limpopo in 2016.

\section{References}

'Murder rate high by 4.9\%'. 2016. Citizen. 2 September. [Online] http://citizen.co.za/news/ news-national/1273010/livereport-annual/ (16 January 2017).

Aina, L.O. 2004. Library and information science text for Africa. Ibadan: Third World Information Services Limited.

Arko-cobbah, A. 2005. Civil society and good governance: challenges for public libraries in South Africa. Library Review, 55(6): 349-362.

Bothma, T.J.D. and Bergenholtz, H. 2013. Information needs changing over time: a critical discussion. South African Journal of Libraries and Information Science, 79(1): 22-34.

Braun, L.W., Hartman, M.L., Hughes-Hassell, S. and Kumasi, K. 2014. The future of library services for and with teens: a call to action. Chicago: ALA. [Online] http://www.ala.org/yaforum/sites/ala.org.yaforum/files/content/YALSA nationalforum_final.pdf (08 December 2016).

Case, D.O. 2012. Looking for information: a survey of research on information seeking, needs and behaviour. $3^{\text {rd }}$ ed. London: Emerald Group Publishing Limited.

9. The Minister of Police, Nkosinathi Nhleko, announced the national crime statistics as reported between 1 April 2015 and 31 March 2016 According to the statistics, overall crime in the country decreased between 2015 and 2016, with 2,1 million crimes reported in the twelve months measured compared to 2,206 million in the previous year. However, Limpopo is one of the two provinces in which crime has increased while all other provinces have shown a decrease. Murder has increased by 121 cases - from 777 in 2015 to 898 in 2016. Crimes such as common assault, sexual offences, murder, attempted murder, aggravated robbery and hi-jacking increased significantly. Comparing the previous year's statistics to that of 2016, crimes in the three major categories (murder, sexual offences, and attempted murder) have all increased. Contact crimes, including murder, sexual assault and attempted murder, have gone up by $6,4 \%$ in Limpopo in the last year with an overall increase of 40,391 crimes reported. Cases of attempted murder have increased by 82 cases from 793 in 2015 to 875 in 2016. Most crimes in Limpopo are of a sexual nature and, although this figure has decreased nationally, it has increased in Limpopo from 4,312 cases in 2015 to 4,396 in 2016 . Robbery with aggravating circumstances saw a $9,8 \%$ increase in the province, while theft of motor vehicles and motorcycles saw a $16,5 \%$ increase ('Murder rate high by $4.9 \%$ ' 2016). 
Chowdhury G.G. and Chowdhury, S. 2011. Information users and usability in the information age. London: Facet Publishing.

Davis, G. 2009. Towards a transformed library and information sector in South Africa: rethinking roles. South African Journal of Libraries and Information Science, 75(2): 131-137.

Department of Arts and Culture and National Library of South Africa. 2014. The South African Libraries 20 years review. [Online]. http://www.nlsa.ac.za/nlsanews/2014/NLSA_Newsletter_Elec.pdf (31 March 2017).

Department of Welfare. 1997. White paper for social welfare: principles, guidelines, recommendations, proposed policies and programmes for developmental social welfare in South Africa. Pretoria: Government Printer. [Online] http://www.gov.za/sites/www.gov.za/files/White_Paper_on_Social_Welfare_0.pdf (27 January 2017).

Evans, E. 1992. Needs analysis and collection development for culturally diverse populations. Collection Building, 11(4): 16-27.

Evans, E. and Saponaro, M.Z. 2012. Collection Management Basics. $6^{\text {th }}$ ed. California: Libraries Unlimited.

Fourie, I. and Meyer, A. 2016. Role of libraries in developing an informed and educated nation. Library Hi Tech, 34(3): 111.

Fourie, J.A. 2007. Educational and vocational guidance and information services for the youth in public libraries. South African Journal of Libraries and Information Science, 73 (1): 51-63.

Hart, G. 2004. Public libraries in South Africa - agents or victims of change? South African Journal of Libraries and Information Science, 70(2): 110-120.

Hart, G. 2010. New vision, new goals, new markets? Reflections on a South African case study of community library services. South African Journal of Libraries and Information Science, 76(2): 81-90.

Hart, G. and Nassimbeni, M. 2013. From Borders and landscape to ecosystem: reconfiguring library services to meet the needs of the South African youth. South African Journal of Libraries and Information Science, 79(1): 13-21.

Heinström, J. 2003. Five personality dimensions and their influence on information behaviour. Information Research, 9(1) paper 165 [Online]. http://InformationR.net/ir/9-1paper165.html (15 March 2017).

International Federation of Library Associations and Institutions. 1994. IFLA/UNESCO Public Library Manifesto [Online]. http://www.ifla.org/publications/iflaunesco-public-library-manifesto-1994 (27 May 2016).

Kebede, C. 2002. The changing information needs of users in electronic environments. The Electronic Library, 20(1): 1221.

Kumar, K. 2008. Library organization. New Delhi: Vikas Publishing.

Limpopo Department of Sport, Arts and Culture. 2015. Annual Performance Plan 2014/15. [Online]. http://www.sac.limpopo.gov.za/sstaff/pages/sites/dsac/documents/annual reports/LDSAC\%20APP\%202014\%2015\%20FINACIAL\%20YEAR.pdf (18 January 2017).

Maepa, E.M. 2000. Information needs and information seeking patterns of the rural people in the Northern Province. D.Litt. et Phil. Thesis. University of Johannesburg.

Malotle, A. and Selwana, K. 2016. The impact of the public libraries and community libraries conditional grant. In The State of Conditional Grant Funded Libraries in South Africa. Department of Art and Culture and National Council for Library and Information Services: National Library of South Africa.

Matolong, H. 2014. Announcing Mzansi on-line: Global Libraries Pilot Project. Pretoria: NLSA. [Online]. http://www.nlsa.ac.za/nlsanews/2014/Qtr3/global_libraries.html (29 November 2016).

Mnkeni-Saurombe, N. 2010. Impact of the 2009 economic recession on public /community library services in South Africa: perceptions of librarians from the metropolitan municipality of Tshwane. Mousaion, 28(1): 89-105.

Mokgaboki, S.N. 2002. Extending community and library services to rural areas - the challenges that lie ahead. South African Journal of Libraries and Information Science, 68 (1): 78-79.

The National Library of South Africa. 2012. The directory of public and community libraries in South Africa [Online] http://www.nlsa.ac.za/downloads/Publications/Libraries_Add_Book.pdf (27 May 2015).

Nicholas, D. 2000. Assessing information needs: tools, techniques and concepts in the information age. London: Aslib.

Niedzwiedzka, B. 2003. A proposed general model of information behaviour. Information Research, 9(1). [Online]. http://informationr.net/ir/9-1/paper164.html (28 November 2016).

Nkondo, M., Brown, A., Dick, A., Hart, G., Molawa, S., Nassimbeni, M., Seleti, Y. and Teffo, L.J. 2014. The Library and Information Services (LIS) Transformation Charter. Pretoria: Department of Arts and Culture (DAC) and the National Council for Library and Information Services (NCLIS). [Online]. http://www.nlsa.ac.za/Downloads_01/2014_Final_LIS_Transformation_Charter.pdf (27 March 2015).

Ocholla, D. 2006. Information accessibility by the marginalised communities in South Africa and the role of libraries. Paper presented at the 72nd IFLA General Conference and Council. 20-24 august 2006. Seoul, Korea. [Online]. http://arizona.openrepository.com/arizona/bitstream/10150/105134/1/Ocholla+Faife+ifla+2006+October+2006+6th.pd f (10 March 2016).

Republic of South Africa. 2008. National Youth Policy 2014-2019. [Online]. http://www.gov.za/documents/national-youthpolicy-2009-2014 (30 January 2017).

Rodrigues, A., Jacobs, L. and Cloete, L. 2006. Providing equitable public library services to South Africa's multicultural communities. Mousaion, 24(2): 211-231.

Schoombee, R., Cloete, L.M. and Jacobs, L. 2008. Interventions in community library services for HIV /AIDS awareness: a case study in the Bojanala region. Mousaion, 25(1): 16-45. 
Stilwell, C. 1989. Community libraries: a brief review of their origins and nature with particular reference to South Africa. Journal of Librarianship, 21(4): 261-267.

Wilson, T.D. 1981. On user education studies and information needs. Journal of documentation, 37: 3-15.

Wilson, T.D. 1994. Information needs and users: fifty years of progress. In Fifty years of information progress: a Journal of Documentation review, B.C. Vickery, Ed. London: Aslib..15 -51.

Wilson, T.D. 1997. Information behaviour: an interdisciplinary perspective. Information Processing and Management, 33(4): 551-572.

Wilson, T.D. 1999. Models in information behaviour research. Journal of Documentation, 55(3): 249-270.

Wishart, E. 2012. Libraries and information provision for African relief. Reading \& Writing, 3(1). DOI:10.4102/rw. v3i1.20.

Witbooi, S.L. 2007. Current developments in public libraries in South Africa. In Libraries for the future: progress and development of South African libraries. T.J.D Botha, P.G. Underwood and P. Ngulube, Eds. Durban: LIASA \& IFLA. 61-70.

Worcester, L. and Westbrook, L. 2004. Ways of knowing: community information -needs analysis. Texas Library Journal, Fall: 102-107. 